\title{
THE IMMUNE RESPONSE OF HUMAN BEINGS TO BRIEF INFECTIONS WITH PNEUMOCOCCUS ${ }^{1}$
}

\author{
By MICHAEL HEIDELBERGER AND DONALD G. ANDERSON \\ (From the Department of Medicine, College of Physicians and Surgeons, Columbia University, and \\ the Presbyterian Hospital, New York City)
}

(Received for publication August 3, 1942)

As a result of qualitative and relative tests $(1,2)$, it is generally agreed that rapid termination of lobar pneumonia in man by means of drugs of the sulfanilamide group does not prevent development of the immune response long recognized as characteristic of spontaneous recovery from the disease and evidenced by the formation of type-specific anticarbohydrate. Nothing is known, however, of the magnitude of this immune response in absolute terms, beyond a single report of $0.15 \mathrm{mgm}$. of anticarbohydrate nitrogen per $\mathrm{ml}$. in the serum of a patient during convalescence from lobar pneumonia due to Type I pneumococcus (3). This patient had received neither serum nor curative drug. The present series of measurements is therefore believed to be the first extended quantitative record of an immune response of human beings to a typical, relatively brief period of infection. Several cases treated with penicillin are included in the series. Since detailed clinical studies on similar case material, in which only qualitative, or relative, immunological methods were used, have already been published, as noted herein, emphasis will be given rather to the new methods used and the deductions made from the analytical data. It is hoped that these methods may be found applicable to other problems of clinical research.

A serious complicating factor was discovered in the course of this and parallel studies. One of the immunologically active components of pneumococci of all types, even of the unencapsulated forms which are devoid of type-specificity, is the somatic polysaccharide or "C"-substance (4). It was found, in an investigation to be published elsewhere, that while the sera of normal persons contained no more than traces, at most, of antibodies to the type-specific polysaccharides

\footnotetext{
1 The work reported in this communication was carried out under the Harkness Research Fund of the Presbyterian Hospital, New York.
}

of Types I, II, III, IV, and V pneumococci, almost all contained measurable amounts of antibody to pneumococcus $\mathrm{C}$-substance. Hence, before a reliable assay could be obtained of the type-specific antibody response in pneumonia patients, it was all the more necessary to remove anti-C in a preliminary absorption, since almost all samples of the type-specific carbohydrates contain C-substance as an impurity. Thus, variable quantities of anti-C would be precipitated with the type-specific antibody and gross errors might result. In the work now to be reported, this preliminary absorption was carried out quantitatively and the figures are included in the table.

\section{CASES}

Twenty-three adult patients, hospitalized for pneumococcal infections, were studied. One patient (III-2) was admitted with a physical examination and history typical of an acute meningitis following an acute otitis media. Pneumococcus Type III was cultured from the infected ear, but the spinal fluid cultures were consistently negative. The remaining patients had pneumonia; of these, 16 presented the classical picture of lobar pneumonia.

All patients received sulfathiazole, sulfadiazine, or penicillin therapy, and blood concentrations were maintained at adequate levels as long as appeared indicated. Data from the patients' charts are included in Table I.

\section{ANALYSES FOR ANTIBODY CONTENT}

The method used was that previously reported (5). Merthiolate $^{2}$ up to $1: 10,000$ was added to all sera and analyses were run under conditions favoring sterility, owing to the long period involved. In order to avoid the uncertainties due to human complement (6), this was first removed from the sera by admixture of triplicate 3 to $4.5 \mathrm{ml}$. portions with $1 \mathrm{ml}$. of a dilution of rabbit anti-egg albumin serum containing about $0.4 \mathrm{mgm}$. of antibody nitrogen and $1 \mathrm{ml}$. of a 0.9 per cent saline solution of crystalline egg albumin (Ea) containing about $0.04 \mathrm{mgm}$. of $\mathrm{Ea} \mathrm{N}$. This was found preferable to heat inactivation, which destroyed a portion of the antibody in sera of low

\footnotetext{
2 Manufactured by Eli Lilly and Co., Indianapolis.
} 
TABLE I

Clinical summary and precipitin response of patients with pneumococcal infections

\begin{tabular}{|c|c|c|c|c|c|c|c|c|c|}
\hline $\begin{array}{l}\text { Pneumococcus } \\
\text { type, case } \\
\text { number }\end{array}$ & $\begin{array}{l}\text { Age of } \\
\text { patient }\end{array}$ & $\begin{array}{l}\text { Lobes } \\
\text { involved }\end{array}$ & $\begin{array}{c}\text { Blood } \\
\text { culture }\end{array}$ & $\begin{array}{l}\text { Approx. day } \\
\text { of disease } \\
\text { drug started }\end{array}$ & $\begin{array}{l}\text { First whole } \\
\text { day temp. } \\
<100^{\circ}\end{array}$ & $\begin{array}{c}\text { Further days } \\
\text { to serum } \\
\text { sample } \\
\text { analyzed }\end{array}$ & $\begin{array}{l}\text { Antibody } \\
\text { to pneumo- } \\
\text { coccus "C" } \\
\text { substance }\end{array}$ & $\begin{array}{c}\text { Homologous } \\
\text { anticarbo- } \\
\text { hydrate }\end{array}$ & $\begin{array}{l}\text { Pneumococcus } \\
\text { antiprotein } \\
\text { (total N) }\end{array}$ \\
\hline & years & & & & & & \multicolumn{3}{|c|}{$m g m . ~ N$ per $4 \mathrm{ml}$. serum } \\
\hline
\end{tabular}

LOBAR PNEUMONIA

\begin{tabular}{|c|c|c|c|c|c|c|c|c|c|}
\hline 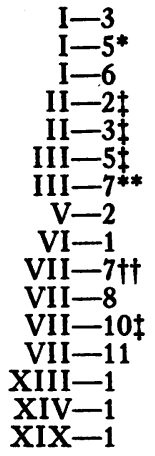 & $\begin{array}{l}34 \\
64 \\
38 \\
36 \\
38 \\
43 \\
49 \\
70 \\
22 \\
56 \\
63 \\
37 \\
49 \\
56 \\
28 \\
52\end{array}$ & $\begin{array}{l}1 \\
1 \\
1 \\
1 \\
1 \\
1 \\
1 \\
1 \\
1 \\
1 \\
1 \\
1 \\
1 \\
2 \\
1 \\
1\end{array}$ & $\begin{array}{l}- \\
- \\
- \\
- \\
- \\
+ \\
- \\
+ \\
- \\
- \\
-\end{array}$ & $\begin{array}{r}>4 \\
3 \\
3 \\
2 \\
2 \\
2 \\
2 \\
2 \\
1 \\
4 \\
4 \\
3 \\
4 \\
3 \\
3 \\
3 \\
4\end{array}$ & $\begin{array}{r}22 \\
8 \\
7 \\
\\
9 \\
6 \\
9 \\
1 \\
5 \\
6,14 \\
\\
9 \\
11 \\
8 \\
6,8\end{array}$ & $\begin{array}{r}120 \\
8 \\
8 \\
3 \\
9 \\
34 \\
10 \\
3 \\
6 \\
11 \\
10 \\
7 \\
7 \\
12 \\
8 \\
7\end{array}$ & $\begin{array}{l}0.009 \\
0.027 \\
0.018 \dagger \\
0.036 \\
0.023 \\
0.010 \\
0.032 \\
0.051 \\
0.143 \\
0.045 \\
0.013 \\
0.053 \\
0.051 \\
0.114 \\
0.078 \\
0.019\end{array}$ & $\begin{array}{l}0.001 \\
0.017 \\
0.025 \dagger \\
0.498 \mid \\
0.026 \\
0.001 \\
0.012 \\
0.286 \\
0 \\
0.006 \\
0.062 \\
0.067 \\
0.138 \\
0.003 \\
0.019 \\
0.016\end{array}$ & $\begin{array}{l}0.027 \\
0.002 \\
0.003 \\
0.017 \\
\\
0.007 \\
0.010\end{array}$ \\
\hline
\end{tabular}

BRONCHIAL PNEUMONIA

\begin{tabular}{l|l|l|l|r|r|r|r|r|r}
\hline III-4 & 33 & & - & 3 & 5 & 4 & 0.026 & 0.009 & 0.003 \\
III-6 & 51 & & - & 2 & 9 & 7 & 0.045 & 0.005 & 0.003 \\
XVII-6 & 60 & & - & 4 & 11 & 12 & 0.004 & 0.123 & \\
XIX-2 & 57 & & & 14 & 17 & 17 & 0.030 & 0.002 & \\
XXIX-1 & 71 & & - & 4 & 8 & 4 & 0.097 & 0.064 & \\
\hline
\end{tabular}

Patients were treated with sulfadiazine unless otherwise noted.

* Received penicillin and then sulfadiazine. Agglutination titer of serum, $1: 2$.

$\dagger$ Independent analyses on another portion of the same serum sample again gave $0.018,0.025 \mathrm{mgm}$. $\mathrm{N}$ for anti-C and anti-I, respectively.

$\ddagger$ Treated with penicillin.

I) Antibody $\mathrm{N}$ by micro-Kjeldahl method, $0.510 \mathrm{mgm}$. Agglutination titer, $1: 64$ to 128.

** Infection resistant to sulfadiazine, treated with penicillin.

t† No drug-treatment.

$\$$ Micro-Kjeldahl. Antibody $\mathrm{N}$ per $4 \mathrm{ml}$., without prior removal of anti-C, $0.333 \mathrm{mgm}$. A serum sample taken 32 days earlier, from which the anti-C was not first removed, showed $0.37 \mathrm{mgm}$. antibody $\mathrm{N}$ per $4 \mathrm{ml}$.

A rabbit antipneumococcus Type I serum pool, diluted to an antibody content of $0.5 \mathrm{mgm}$. $\mathrm{N}$ per $4 \mathrm{ml}$., showed an agglutination titer of $1: 40$ under the conditions used in estimating the 2 titers given above. Titers and antibody contents were roughly parallel in the 3 instances.

content but was permissible with the stronger sera. The Ea-anti-Ea precipitations were carried out at room temperature and allowed to stand until the precipitates flocked (7), after which the tubes were left in the ice-box for 48 hours and centrifuged in the cold.?

Aliquot portions of the supernatants were set up as follows in sterile, tapered, Pyrex centrifuge tubes of about $7.5 \mathrm{ml}$. capacity. Three portions were measured out, one serving as a blank. To the other two, 0.01 or 0.02 fuge. mgm. of pneumococcus C-substance was added in a volume of 0.1 or $0.2 \mathrm{ml}$. It was found essential to use C-substance derived from a type of pneumococcus other than that causing the infection in the patient whose serum was being analyzed, for it is as difficult to remove the last traces of type-specific substance from a sample of C-carbohydrate as to eliminate the last residues of $\mathrm{C}$-substance from samples of type-specific carbohydrate. Alternatively, C-substance, derived from wholly degraded pneumococcus $R$ (Dawson S) strains free from type-specific carbohydrate, may be used to advantage.

The contents of the tubes were thoroughly mixed with a 
thin sterile glass rod or by rapid twirling. After capping with sterile rubber caps the tubes were placed in a waterbath at $37^{\circ} \mathrm{C}$. for one-half to one hour and were then allowed to stand 8 days in the ice-box, with occasional twirling. In the strongest sera, precipitates often formed overnight but most of the weaker sera remained clear and required several days before the first small floccules separated. The tubes were finally centrifuged in the cold. The supernatants of tubes in which relatively large precipitates had formed were allowed to stand another 8 days after mixing with an additional 0.01 or $0.02 \mathrm{mgm}$. of $\mathrm{C}$-carbohydrate. The precipitates and blanks were washed in the cold in the usual way (8) with chilled saline, stirring well, or twirling vigorously to ensure maximum disintegration of the precipitate and thorough mixing. When a stirring rod was used, it was rinsed down with a little chilled saline. Supernatants from the washings were often recentrifuged in order to recover any precipitate carried over, usually combining the washings from duplicates in larger centrifuge tubes. A third washing was usually given the tubes in which the washings were recentrifuged. Precipitates were dissolved in a few drops of $0.1 \mathrm{~N}$ sodium hydroxide, using a hand lens if necessary to make sure that the sometimes glassy precipitate was completely dissolved. The solution of the traces of precipitate recovered on recentrifugation was divided approximately equally among the 2 duplicates. The volumes were then made up with water to a calibration mark (usually $2.5 \mathrm{ml}$.) in the tubes, or the solutions were transferred to 5.0 or $10.0 \mathrm{ml}$. measuring flasks when the precipitates were relatively heavy. Two ml. portions of the duplicate solutions of dissolved precipitate were analyzed for nitrogen (5). One hundred th to $0.04 \mathrm{mgm}$. of protein or antibody nitrogen in the aliquot proved most satisfactory, and in this range, successive determinations usually varied by only a few thousandths of a mgm. The tyrosine color value of the antibody was checked by direct comparison of the colorimetric with the micro-Kjeldahl method.

The supernatant sera from the anti- $\mathrm{C}$ analyses, including the blank, were carefully drained into sterile centrifuge tubes, such as those suggested above. To the duplicates from the anti-C estimations were then added amounts of the homologous type-specific carbohydrate, depending upon the result of a preliminary test with $1 \mathrm{ml}$. of the patient's serum. Usually, 0.005 to $0.05 \mathrm{mgm}$. sufficed. The analyses were carried out in the same manner as

\footnotetext{
In this preliminary note, the directions on p. 405 should read: "Aliquots of $2.0 \mathrm{ml}$. are mixed with $6 \mathrm{ml}$. of clear 12.5 per cent $\mathrm{Na}_{2} \mathrm{CO}_{3}$ solution and $1 \mathrm{ml}$. of 0.1 per cent $\mathrm{CuSO}_{4} \cdot 5 \mathrm{H}_{2} \mathrm{O}$ solution and allowed. . . ."

The specific polysaccharides of Types I, II, III, and VIII pneumococcus were prepared in this laboratory according to (9). The others were furnished through the courtesy of Drs. W. E. Bunney and J. Palmer of E. R. Squibb \& Sons, New Brunswick, N. J., and Drs. A. B. Wadsworth and Rachel Brown of the New York State Dept. of Health Research Laboratories, Albany, New York.
}

those for anti-C and supernatants were treated with more specific polysaccharide if the precipitates were relatively large. In occasional sera, such as II-2 and III-2, precipitates formed almost as quickly as in hyperimmune rabbit sera and analyses could be carried out by the microKjeldahl method (8), or as described above with as little as $1 \mathrm{ml}$. of serum.

After removal of anti-C and type-specific antibody, most of the sera from cases infected with pneumococci of types other than VII gave small precipitates with the specific polysaccharide of Type VII pneumococcus as well, but as the amounts rarely exceeded a few thousandths of a mgm. of nitrogen, the significance of these precipitates is doubtful. Possibly, they represented additional traces of anticarbohydrate which would have been included in the preceding analyses had they been allowed to stand even longer. However, the formation of these precipitates makes it appear less probable in the Type VII cases than in those of the other types that the entire type-specific antibody response was due to the immediately preceding infection.

A few sera were also analyzed for antibody to pneumococcus protein after the anti-carbohydrate analyses were completed and the data so obtained are included in the table. Finally, supernatants were tested with appropriate immune rabbit or horse sera to make sure that an excess of C, type-specific carbohydrate, or protein had been used in the analyses.

The procedure, while laborious and time-consuming, is especially well adapted to the analysis of large numbers of sera, as the work may readily be planned so that analyses on sets of 4 to 6 sera become due daily.

In order to determine whether the anti-C values represented true antibody to the somatic polysaccharide of pneumococcus, or consisted wholly or in part of " $\mathrm{C}$-protein," the material reactive with C-substance in the albumin fraction of the serum of febrile cases $(4,10)$, the following experiment was carried out:

A pool was made of 3 sera which had averaged about 0.1 mgm. of anti-C per $4 \mathrm{ml}$., an unusually large amount. Twenty-four and a half $\mathrm{ml}$. were diluted with $25 \mathrm{ml}$. of water and the globulin fraction, which would presumably contain true antibody to C-polysaccharide, was precipitated by addition of $49.5 \mathrm{ml}$. of warm saturated sodium sulfate solution. The precipitate $(A)$ was centrifuged off as sharply as possible and a fraction $(B)$ was precipitated from the supernatant by addition of $50 \mathrm{ml}$. of warm saturated sodium sulfate solution, as recommended (10b) for the separation of the albumin fraction containing any "C-protein" present. This was filtered off after standing overnight. Both $A$ and $B$ were dissolved in water with the aid of a drop of $\mathrm{N}$ sodium bicarbonate solution, di-

- In a detailed analytical paper in preparation for publication, it is shown that known quantities of type-specific antibody from horse or rabbit antipneumococcus sera added to normal horse or rabbit serum $(0.010$ to $0.040 \mathrm{mgm}$. of antibody nitrogen per $4 \mathrm{ml}$. of serum) are recoverable to the extent of 80 to 90 per cent by the method. 
alyzed in the cold against several changes of 0.9 per cent saline, made up to $1: 10,000$ with merthiolate, and finally centrifuged. The volume of $A$ was $22 \mathrm{ml}$., that of $B, 18$ ml. Analyses for anti-C were carried out with the largest possible blank and duplicate portions, as described above, yielding, after several successive additions of $\mathrm{C}$-substance, $0.123 \mathrm{mgm}$. anti-C nitrogen in the globulin fraction $A$ and zero anti-C in the albumin fraction $B$, even after addition of $10 \mathrm{mgm}$. of calcium chloride to the latter in case absence of precipitation had been due to a lack of calcium ion.

\section{DISCUSSION}

As previously noted (6), the estimation of small quantities of antibody in human sera presents unexpected difficulties and these are added to in the study of antibodies to pneumococcus by the normal occurrence of antibodies to the somatic carbohydrate or C-substance of this microorganism. These antibodies differ from the anti-C present in febrile attacks due to many microorganisms $(4,10)$ in the time of their appearance, in their occurrence with other antibodies in the globulin fraction, and in that the specific precipitates which they form with $\mathrm{C}$ do not require the addition of calcium ion in order to keep them in an insoluble form. The reason for the presence of anti- $C$ in normal humans remains uncertain, although it may be recalled that pneumococci are usual inhabitants of the human nose and throat. Possibly C-substance in antigenic combination with protein, as in meningococci and hemolytic streptococci (11), is a dominant antigen of these non-pathogenic forms anp makes its presence evident in varying degreei As noted in the table, the anti-C content of a patient's serum is of ten equal to or greater than that of the type-specific antibody elicited by the infection. That the latter actually arises from the infection seems evident from numerous analyses on normal sera carried out in this laboratory with a variety of type-specific polysaccharides. Such response as was indicated in a few instances was usually traceable to the C-substance in the type-specific carbohydrate used except that, in the case of the type VII polysaccharide, a small residuum of type-specific antibody was evident in a fair proportion of normal sera. In only one instance (VI-1) was a sample of serum available prior to the pneumococcus infection. In this case, the unusually high anti-C content was present before the attack of lobar pneumonia, as well as after, and failed to protect the patient from infection with Type VI pneumococcus.

With regard to the analytical technic, the use of type-specific pneumococcus suspensions did not appear suitable for the determination of antibodies in the sera of humans convalescent from pneumonia owing to the ordinarily. small difference between the nitrogen in the washed pneumococcus suspension used for the analysis and the total nitrogen after addition of the antibody, a difference often of the same order of magnitude as the analytical errors in the method. When type-specific polysaccharides were used, instead, for precipitation of the antibody, it was not only found that deposition of specific precipitate was usually incomplete in the time ordinarily allotted (8), but also that the complement present in fresh human sera introduced further uncertainties. These have been more fully discussed elsewhere (6). Removal of the complement by heat inactivation seriously damaged the small amounts of anticarbohydrate present in the weaker convalescent sera, but elimination of complement was successfully accomplished by its fixation to an unrelated immune system such as egg albumin-anti-egg albumin. Analysis of the decomplemented sera could then be carried out with precautions to ensure sterility and by allowing the tubes to stand much longer than had been found necessary with the sera of hyperimmunized animals.

By the use of the phenol reagent (5), amounts of antibody, roughly one-tenth those ordinarily necessary for the micro-Kjeldahl modification hitherto used (8), may be estimated with equal accuracy and the scope and utility of the quantitative method is thereby greatly extended. As carried out in this way, the precipitin reaction not only yields quantitative data on antibody content in weight units, but is actually made far more sensitive than the complement fixation reaction in comparable immune systems. While the limiting amounts of antibody nitrogen are roughly of the order of $0.001 \mathrm{mgm}$. per $\mathrm{ml}$. in both reactions $(5,12)$, in complement fixation tests this quantity of antibody must be present at a serum dilution of $1: 5$ or $1: 10$ in order to avoid non-specific or anticomplementary effects. With the new precipitin technic, however, these 
minimal quantities of antibody nitrogen are accurately determinable in undiluted serum, so that sera too weak for complement fixation may be assayed.

As noted in the table, human sera resulting from pneumococcus infections abbreviated or terminated by the use of sulfa drugs or penicillin show an extremely varied immune response on the part of the patient, from complete absence of type-specific anticarbohydrate to a content of antibody almost equal to that reported in an untreated convalescent by Kabat (3). Indeed, the variation is not greater than might be expected in an equal group of rabbits or horses, the two species of animals ordinarily used for the production of antipneumococcus sera. When one considers the length of time necessary and the quantity of pneumococci employed for the production of potent antisera in rabbits and horses, the antibody response of this group of humans to what one might term a short course of immunization would seem just as favorable. ${ }^{7}$

The precise analytical data given above not only indicate the actual content of circulating anticarbohydrate in a representative group of drug-treated pneumococcus infections but also furnish an extension and confirmation of earlier studies on pneumonia patients in which mouse protection or agglutinin titers $(2,13$ to 15$)$ or qualitative precipitin tests $(15 a, 16)$ were evaluated. As in the earlier, relative studies, no correlation appears in the present series between the more obvious clinical factors and the antibody response. Since the wide variation in this response is probably as characteristic for humans as for other animals, it is apparent that a very large number of cases would be needed to establish any such correlation.

Investigation of antibodies to pneumococcus in human sera under various circumstances is being continued.

\section{SUMMARY}

1. Technical details are given for overcoming the difficulties and increasing the sensitivity of precipitin estimations in human sera so that the

7 Entirely comparable analytical data on the sera of rabbits given a single injection of killed Type I pneumococci will be reported in collaboration with Prof. Colin M. MacLeod. results may be used in accurate studies of the antibody response in infectious disease. Pneumococcus anticarbohydrate may now be estimated quantitatively at concentrations lower than detectable qualitatively by complement fixation.

2. Quantitative data, in milligrams of antibody nitrogen per unit of volume, are presented on the immune response of patients to pneumococcal pneumonia and meningitis terminated by sulfa-drug or penicillin therapy. Values are given for the antibodies precipitable by $\mathrm{C}$-polysaccharide, type-specific polysaccharide, and nucleoprotein. The figures found varied from zero to as much as $0.5 \mathrm{mgm}$. of antibody nitrogen per $4 \mathrm{ml}$. of serum.

3. The type-specific anticarbohydrate response in the drug-treated patients was of a magnitude and variability comparable with that of rabbits or horses given a brief course of immunization.

The writers are indebted to numerous members of the clinical staff of the Presbyterian Hospital and to Professors Colin M. MacLeod and William S. Tillett of the New York University Medical School for the sera used, also to Miss Betty Robinson for a number of the analyses.

\section{BIBLIOGRAPHY}

1. Reviewed in Curnen, E. C., and MacLeod, C. M., The effect of sulfapyridine upon the development of immunity to pneumococcus in rabbits. J. Exper. Med., 1942, 75, 77 (cf. p. 79).

2. Tillett, W. S., Specific antipneumococcal immunity in relation to the chemotherapy of pneumonia. J. Clin. Invest., 1942, 21, 511.

3. Kabat, E. A., The molecular weight of antibodies. J. Exper. Med., 1939, 69, 103 (cf. p. 105).

4. a. Tillett, W. S., and Francis, T., Jr., Serological reactions in pneumonia with a non-protein somatic fraction of pneumococcus. J. Exper. Med., 1930, $52,561$.

b. Tillett, W. S., Goebel, W. F., and Avery, O. T., Chemical and immunological properties of a speciesspecific carbohydrate of pneumococci. J. Exper. Med., 1930, 52, 895.

c. Heidelberger, M., and Kendall, F. E., Specific and non-specific polysaccharides of Type IV pneumococcus. J. Exper. Med., 1931, 53, 625.

5. Heidelberger, M., and MacPherson, C. F. C., Quantitative micro-estimation of antibodies in the sera of man and other animals. Science, 1943, 97, 405; 98, 63.

6. Heidelberger, M., and Mayer, M., Quantitative chemical studies on complement or alexin. IV. Addition of human complement to specific precipitates. J. Exper. Med., 1942, 75, 285. 
7. Heidelberger, M., Quantitative chemical studies on complement or alexin. I. A method. J. Exper. Med., 1941, 73, 681.

8. a. Heidelberger, M., and Kendall, F. E., The precipitin reaction between Type III pneumococcus polysaccharide and homologous antibody. II. Conditions for quantitative precipitation of antibody in horse sera. J. Exper. Med., 1935, 61, 559.

b. Heidelberger, M., and Kendall, F. E., The reaction between crystalline egg albumin and its homologous antibody. J. Exper. Med., 1935, 62, 697.

9. Heidelberger, M., Kendall, F. E., and Scherp, H. W., The specific polysaccharides of Types I, II and III pneumococcus. J. Exper. Med., 1936, 64, 559.

10. a. Abernethy, T. J., and Avery, O. T., The occurrence during acute infections of a protein not normally present in the blood. I. Distribution of the reactive protein in patients' sera and the effect of calcium on the flocculation reaction with $\mathbf{C}$ polysaccharide of pneumococcus. J. Exper. Med., 1941, 73, 173.

b. MacLeod, C. M., and Avery, O. T., II. Isolation and properties of the reactive protein. J. Exper. Med., 1941, 73, 183.

c. MacLeod, C. M., and Avery, O. T., III. Immunological properties of the $\mathrm{C}$-reactive protein and its differentiation from normal blood proteins. J. Exper. Med., 1941, 73, 191.

d. Perlman, E., Bullowa, J. G. M., and Goodkind, R., An immunological and electrophoretic comparison of the antibody to C-polysaccharide and the C-reactive protein of acute phase serum. J. Exper. Med., 1943, 77, 97.
11. a. Miller, C. P., and Boor, A. K., The carbohydrates of gonococcus and meningococcus. J. Exper. Med., 1934, 59, 75.

b. Heidelberger, M., and Kendall, F. E., Carbohydratecontaining proteins of the hemolytic streptococcus. J. Immunol., 1936, 30, 267.

12. Heidelberger, M., Weil, A. J., and Treffers, H. P., Quantitative chemical studies on complement or alexin. II. The interrelation of complement with antigen-antibody compounds and with sensitized red cells. J. Exper. Med., 1941, 73, 695.

13. Wood, W. B., Jr., and Long, P. H., Observations on the experimental and clinical use of sulfapyridine. III. The mechanism of recovery from pneumococcal pneumonia in patients treated with sulfapyridine. Ann. Int. Med., 1939, 13, 612.

14. Finland, M., Spring, W. C., Jr., and Lowell, F. C., Immunological studies on patients with pneumococcic pneumonia treated with sulfapyridine. J. Clin. Invest., 1940, 19, 179.

15. a. Finland, M., Strauss, E., and Peterson, O. L., Antibody response of patients with pneumococcic pneumonia treated with sulfadiazine and sulfathiazole. Ann. Int. Med., 1942, 16, 1.

b. Finland, M., and Shuman, H. I., The type-specific agglutinin response of infants and children with pneumococcal pneumonias. J. Immunol., 1942, 45, 215.

16. Kneeland, Y., Jr., and Mulliken, B., Antibody formation in cases of lobar pneumonia treated with sulfathiazole. J. Clin. Invest., 1940, 19, 735. 